\title{
PENGEMBANGAN LKPD BERORIENTASI REACT STRATEGY PADA MATERI MOMENTUM DAN IMPULS
}

\author{
Winda Tri Wulandari, Dedy Hamdani, Sutarno
}

\author{
Program Studi Pendidikan Fisika, Fakultas Keguruan dan Ilmu Pendidikan, Universitas Bengkulu \\ Jl. WR. Supratman, Kandang Limun, Bengkulu \\ E-mail*: windatw@yahoo.com
}

\begin{tabular}{c|c|c}
\hline Diterima 20 Juli 2020 & Disetujui 6 Agustus 2020 & Dipublikasikan 31 Agustus 2020 \\
\hline & https://doi.org/10.33369/jkf.3.2.151-162 \\
\hline
\end{tabular}

\begin{abstract}
ABSTRAK
Penilitian ini bertujuan untuk : 1) menghasilkan LKPD berorientasi REACT strategy yang layak dan dapat digunakan pada materi momentum dan impuls; 2) mendeskripsikan karakteristik LKPD berorientasi REACT strategy yang telah dikembangkan pada materi momentum dan impuls. Metode penelitian yang akan digunakan untuk pengembangan LKPD berorientasi REACT strategy. Penelitian ini merupakan penelitian dan pengembangan (research and development) dengan model 4-D, dimana pada penelitian hanya dilakukan sampai tahap Develop. Berdasarkan hasil uji validasi produk oleh ahli didapatkan skor rata-rata dengan persentase sebesar $73,3 \%$ pada aspek media, $84,5 \%$ pada aspek materi, dan $80 \%$ pada aspek bahasa. Berdasarkan hasil tersebut, dapat disimpulkan bahwa LKPD beorientasi REACT strategy yang dihasilkan sudah valid dengan persentase rata-rata sebesar 79,3\%. Adapun karakteristik LKPD yang dikembangkan terdapat tahapan-tahapan dari REACT strategy.
\end{abstract}

Kata kunci: Penelitian dan Pengembangan, LKPD, REACT strategy, momentum dan impuls.

\begin{abstract}
The research aimed to: 1) produce LKPD with suitable REACT strategy orientation and can use for momentum and impulses materials; 2) describe LKPD characteristics with REACT strategy orientation that have developed in momentum and impulse materials. This research was a research and development (research and development) with a 4D model, which was only carried out until the develop stage. Based on the results of the product validation test by experts obtained an avarage score $73,3 \%$ for media aspects, $84,5 \%$ for material aspects, and $80 \%$ for language aspects. Based on these results obtained conclusions that LKPD with REACT strategy orientation that produced is valid with percentage about 79,3\%. As for LKPD characteristics that developed discoverd several steps in REACT strategy.
\end{abstract}

Keywords: Research and Development, LKPD, REACT Strategy, Momentum and Impulses.

\section{PENDAHULUAN}

Ilmu fisika merupakan ilmu yang selalu mengalami perkembangan dan berperan penting dalam peningkatan mutu pendidikan, oleh karena itu diberikan perhatian yang lebih besar terhadap pengajaran fisika disetiap jenjang pendidikan (1). Ilmu fisika mempelajari tentang gejala alam yang memiliki hubungan erat dengan fakta, konsep, prinsip, hukum, serta proses yang menuntut kemampuan peserta didik untuk berpikir (2).

Berdasarkan hasil observasi yang dilakukan saat magang 2 di SMA Negeri 9 Kota Bengkulu diperoleh informasi bahwa keterbatasan bahan ajar menjadi salah satu masalah dalam pembelajaran fisika. Bahan ajar yang digunakan belum bervariasi hanya menggunakan buku paket yang ada di perpustakaan sekolah dan belum adanya bahan ajar tambahan seperti Lembar Kerja Peserta Didik (LKPD). Sebagian besar peserta didik kelas $\mathrm{X}$ mengatakan bahwa kesulitan dalam memahami pelajaran fisika salah satu alasannya yaitu karena keterbatasan penggunaan bahan ajar, sehingga membutuhkan bahan ajar tambahan lain yang bersifat pribadi dalam membantu memahami pelajaran fisika. Selain itu, pelaksanaan praktikum yang belum maksimal disebabkan oleh penuntun 
praktikum yang ada belum membimbing peserta didik, sehingga peserta didik belum paham dengan penuntun praktikum yang digunakan.

Alternatif yang dapat memfasilitasi peserta didik yaitu dengan adanya pengembangan LKPD, dimana setiap peserta didik dapat menuangkan ide-ide dan pendapatnya dalam memecahkan suatu masalah. Alternatif lainnya pada aktivitas laboratorium dalam bentuk kegiatan praktikum salah satunya dapat melatih keterampilan menerapkan keterampilan inkuiri (3).

Fungsi bahan ajar yang sangat penting dalam kegiatan pembelajaran salah satunya memberikan dasar yang lebih ilmiah terhadap pembelajaran (4). Salah satu bahan ajar yaitu LKPD. LKPD adalah lembaran-lembaran yang berisi latihan soal yang harus dikerjakan oleh peserta didik (5). LKPD merupakan suatu lembaran aktivitas dalam pembelajaran untuk menerapkan atau mempraktekkan ilmu yang telah diperoleh, digunakan untuk mengetahui keberhasilan peserta didik dalam menguasai materi yang telah diberikan (6). Umumnya LKPD yang digunakan di sekolah tak berstruktur dan berisikan materi pelajaran serta petunjuk yang sedikit. LKPD yang digunakan belum menggunakan strategi yang sesuai dengan karakteristik dan kebutuhan peserta didik (7). LKPD sangat baik digunakan untuk membuat peserta didik aktif dalam belajar, dengan adanya LKPD peserta didik dapat membangun pengetahuannya sendiri dan dapat berperan aktif dalam pembelajaran.

Adapun fungsi LKPD menurut Prastowo dalam (8) bahwa LKPD memiliki empat fungsi, sebagai berikut : a) bahan ajar yang bisa meminimalkan peran guru dan membuat peserta didik lebih aktif; b) bahan ajar yang dapat mempermudah peserta didik dalam memahami materi; c) bahan ajar yang memuat latihan soal untuk melatih peserta didik; d) memudahkan proses pembelajaran di kelas.

Strategi pembelajaran merupakan suatu rencana kegiatan yang dirancang untuk mencapai tujuan yang didukung oleh pemilihan keterampilan yang telah dikuasai (9). Salah satu strategi pembelajaran yang tepat berdasarkan kenyataan yang telah dijelaskan yaitu REACT strategy. REACT strategy merupakan strategi yang terdiri dari lima tahapan yaitu relating (mengaitkan), experiencing (mengalami), applying (menerapkan), cooperating (bekerjasama), dan transferring (mentransfer) (10). Melalui tahapan-tahapan ini peserta didik dapat mengaitkan antara materi yang diajarkan dengan kehidupan nyata (11).

REACT strategy dapat membantu guru dan peserta didik untuk membuat hubungan antara konsep mengenai subjek dan konteks yang berasal dari pengalaman kehidupan (12). REACT strategy merupakan strategi yang menuntun peserta didik untuk mengaitkan materi ke kehidupan dunia nyata, belajar dalam konteks eksplorasi, menerapkan pengetahuan yang telah didapatkan, bekerja sama, serta mentransfer pengetahuan yang miliki untuk memecahkan masalah yang dihadapi (13).

REACT merupakan pembelajaran yang didasarkan pada bagaimana cara peserta didik belajar untuk mendapatkan konsep pemahaman dan bagaimana guru mengajarkan untuk memberikan suatu pemahaman kepada peserta didik. LKPD berorientasi REACT strategy dapat membantu guru memberikan pemahaman konsep, sehingga peserta didik mampu mengaitkan pelajaran dengan kehidupan sehari-hari. Peserta didik juga dapat mengalami sendiri menemukan suatu konsep, menerapkannya dalam kehidupan nyata, bekerja sama dan dapat mentransfer pengetahuan yang diperoleh dalam konteks baru (14).

Strategi pembelajaran REACT memiliki beberapa keunggulan antara lain : a) membantu guru untuk mengaitkan materi yang diajarkan dengan kehidupan nyata; b) mendorong peserta didik untuk menerapkan pengetahuan yang dimiliki dalam kehidupan sehari-hari; c) meningkatkan pemahaman peserta didik dengan cara mengaitkan materi dengan kehidupan nyata sehingga materi lebih mudah; d) pada tahap bekerja sama peserta didik diminta aktif untuk kerja sama dengan teman kelompoknya e) meningkatkan kemampuan peserta didik untuk dapat mentransfer konsep pengetahuan ke dalam suatu masalah yang lebih kompleks (15).

LKPD berorientasi REACT strategy merupakan lembar kerja peserta didik yang berisikan petunjuk pengunaan LKPD serta tahapan-tahapan REACT strategy. Adanya REACT strategy peserta didik dapat menghubungkan, mengalami, menerapkan, bekerja sama dan mentransfer pelajaran 
dalam kehidupan sehari-hari. LKPD ini berbeda dengan LKPD pada umumnya karena pada LKPD terdapat pertanyaan, soal dan kegiatan praktikum yang membuat peserta didik menerapkan konsep materi yang didapat saat belajar ke dalam kehidupan nyata. Proses bekerja sama memecahkan masalah saat praktikum dapat dilaksanakan.

Berdasarkan hasil penelitian terdahulu yang mendukung penelitian ini yaitu penelitian yang dilakukan oleh Dewi, Aminah, \& Sukarmin menunjukkan bahwa REACT strategy dapat meningkatkan kecerdasan majemuk dan kreativitas siswa"(10). Berdasarkan literatur dan pengamatan yang telah dilakukan belum banyak dikembangkan LKPD terutama berorientasi REACT strategy pada materi momentum dan impuls. Oleh karena itu dilakukan penelitian dengan judul "Pengembangan LKPD Berorientasi REACT Strategy Pada Materi Momentum Dan Impuls" dengan tujuan penelitian yaitu : 1) Menghasilkan LKPD berorientasi REACT strategy yang layak dan dapat digunakan pada materi momentum dan impuls, 2) Mendeskripsikan karakteristik LKPD berorientasi REACT strategy yang telah dikembangkan pada materi momentum dan impuls.

\section{METODE PENELITIAN}

Metode penelitian yang digunakan untuk pengembangan LKPD berorientasi REACT strategy yaitu metode penelitian dan pengembangan atau Research and Development $(R \& D)$. Produk yang dihasilkan dalam penelitian ini yaitu LKPD berorientasi REACT strategy. Model penelitian ini menggunakan model pengembangan 4-D, tetapi pada penelitian ini dilakukan sampai 3-D yang terdiri dari tiga tahapan yaitu define (pendefinisian), design (perancangan), develop (pengembangan). Tahap-tahap yang digunakan pada penelitian ini dilihat pada gambar 1.

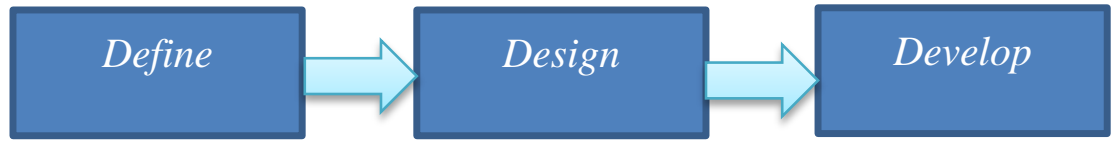

Gambar 1 Metode $R \& D$ Model 3D

Validasi ahli dilakukan dengan menggunakan angket. Lembar angket untuk validasi ahli digunakan untuk mengetahui kelayakan dan efektivitas pengembangan dari LKPD yang telah dikembangkan. Teknik angket ini digunakan sebagai validasi perangkat pembelajaran untuk mengetahui respon ahli terhadap LKPD berorientasi REACT strategy. Peneliti meminta validator untuk mengisi angket dengan cara memberi tanda centang $(\sqrt{ })$ pada angket yang telah disediakan. Interprestasi skala likert dari sumber (16). Angket untuk validator menggunakan lima pilihan jawaban seperti dapat dilihat pada tabel 1 sebagai berikut :

Tabel 1 Interprestasi Skala Likert

\begin{tabular}{cc}
\hline Nilai & Pernyataan \\
\hline 5 & Sangat Baik (SB) \\
4 & Baik (B) \\
3 & Cukup Baik (CB) \\
2 & Tidak Baik (TB) \\
1 & Sangat Tidak Baik (STB) \\
\hline
\end{tabular}

Perhitungan tingkat kelayakan validasi ahli dari LKPD digunakan peneliti untuk mengetahui kelayakan LKPD berorientasi REACT strategy. Untuk menghitung tingkat kelayakan dari LKPD yang dibuat ini digunakan teknik perhitungan rata-rata. Adapun teknik perhitungan rata-rata yang digunakan untuk mengetahui tingkat kelayakan dari produk LKPD diadaptasi dari (17). Rumus persentase digunakan untuk menganalisis data kuantitatif adalah sebagai berikut.

$$
V_{\mathrm{ah}}=\frac{T_{\mathrm{Se}}}{T_{\mathrm{Sh}}} \times 100 \%
$$

Dengan $V_{\text {ah }}$ adalah validasi ahli, $T_{\text {Se }}$ adalah total skor empirik (berdasarkan penilaian ahli), dan $T_{\text {Sh }}$ adalah total skor maksimal (skor yang diharapkan). Kriteria kelayakan penilaian dari ahli dapat dilihat pada tabel 2.

Tabel 2 Kriteria Kelayakan

\begin{tabular}{ccc}
\hline No & Pencapaian Nilai (Skor) & Kategori Validitas \\
\hline 1 & $81 \%-100 \%$ & Sangat valid \\
\hline
\end{tabular}




\begin{tabular}{ccc}
\hline No & Pencapaian Nilai (Skor) & Kategori Validitas \\
\hline 2 & $61 \%-80 \%$ & Valid \\
3 & $41 \%-60 \%$ & Kurang valid \\
4 & $21 \%-80 \%$ & Tidak valid \\
5 & $0 \%-20 \%$ & Sangat tidak valid \\
\hline
\end{tabular}

\section{HASIL DAN PEMBAHASAN}

\subsection{Deskripsi Data Hasil Pengembangan LKPD}

Penelitian ini menghasilkan produk berupa LKPD berorientasi REACT strategy pada materi momentum dan impuls yang telah divalidasi dan diperbaiki berdasarkan saran dari para ahli. Adapun deskripsi data hasil pengembangan untuk setiap tahapan diuraikan berikut ini :

\subsubsection{Define (Pendefinisian)}

Pada tahap define dilakukan kegiatan dengan menganalisis kebutuhan produk. Kegiatan ini dilakukan dengan cara mengumpulkan data analisis kebutuhan dari observasi langsung dan data sekunder atau studi literatur. Data yang dikumpulkan pada tahap ini yaitu data yang nyata sesuai kebutuhan LKPD. Pada tahap define didapat hasil data analisis kebutuhan yaitu : a) Penyusunan instrumen penelitian untuk tahap define; b) hasil lembar observasi; c) hasil analisis kurikulum; d) hasil analisis perangkat pembelajaran LKPD; e) analisis kebutuhan peserta didik; f) analisis kebutuhan guru.

\subsubsection{Design (Perancangan)}

Rancangan LKPD ini dicetak dalam bentuk buku ukuran kertas A5 dengan tampilan menarik dan berwarna. Desain LKPD berorientasi REACT strategy dibuat menggunakan microsoft word 2010 dan photoshop.

Pengembangan LKPD pada cover LKPD berwarna biru dan gambar segi enam warna-warni. Di bawah gambar terdapat judul LKPD yaitu "LKPD BERORIENTASI REACT STRATEGY". Judul LKPD ini ditulis dengan menggunakan jenis huruf cooper black dan font size 22. Disamping kiri judul terdapat logo Universitas Bengkulu, logo ini bertujuan untuk mengetahui asal Universitas peneliti. Logo tersebut berukuran $4 \times 2 \mathrm{~cm}$. Pada bagian tengah dari LKPD terdapat gambar yang menggambarkan materi hukum kekekalan momentum yaitu gambar ayunan bola besi. Pada gambar kedua di bawah gambar bola besi terdapat gambar aplikasi materi impuls dalam kehidupan seharihari yaitu gambar stick dan bola golf. Bagian kanan terdapat kolom identitas peserta didik dengan tulisan berwarna hitam dan jenis huruf time news roman dan font size 12 yang berisikan nama, kelas, dan asal sekolah serta di bawahnya terdapat kolom kecil yang berisikan $\mathrm{X}$ hal ini dengan keterangan bahwa LKPD ditujukan untuk kelas X. Pada bagian bawah sebelah kiri dari LKPD terdapat nama penulis dengan tulisan berwarna putih dan jenis huruf time news roman dan font size 18. Hasil pengembangan cover dapat dilihat pada gambar 2.

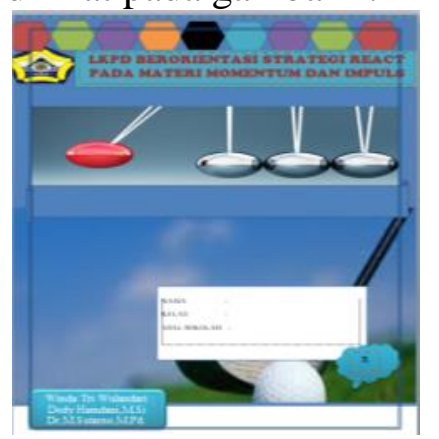

Gambar 2. Hasil Pengembangan Cover LKPD

Pengembangan LKPD pada halaman kata pengantar LKPD berwarna putih dan terdapat gambar segi enam warna-warni disebelah kiri LKPD dengan garis pinggir berwarna biru. Pada halaman kata pengantar meliputi judul "Kata Pengantar" yang bertuliskan jenis huruf time news roman dan font size 14 berwarna hitam. Pada bagian isi dari daftar isi ditulis dengan menggunakan jenis huruf time news roman dan font size 12. Isi kata pengantar terdiri dari 2 paragraf. Di bawah kata pengantar terdapat nama kota, tanggal, dan penulis. Hasil pengembangan tampilan kata pengantar dapat dilihat pada gambar 3. 


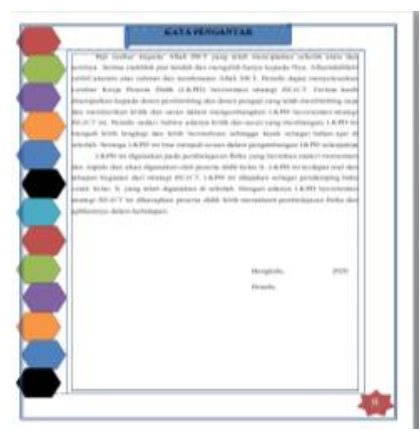

Gambar 3. Hasil Pengembangan Kata Pengantar

Pengembangan LKPD halaman pada petunjuk penggunaan LKPD berwarna putih dan terdapat gambar segi enam warna-warni disebelah kiri LKPD dengan garis pinggir berwarna biru. Pada halaman petunjuk penggunaan LKPD meliputi judul "Petunjuk Penggunaan LKPD" dengan jenis huruf time news roman dan font size 14 berwarna hitam. Bagian isi dari petunjuk penggunaan LKPD ditulis dengan menggunakan jenis huruf time news roman dan font size 12. Isi petunjuk penggunaann LKPD berisikan petunjuk penggunaan dari LKPD berorientasi REACT Strategy.

Pada tahap relating (mengaitkan) diminta untuk menghubungkan konsep yang baru dengan pengetahuan yang dimiliki dalam konteks kehidupan nyata serta pengalaman. Experiencing (mengalami) pada tahap ini diminta untuk belajar secara langsung melalui kegiatan eksplorasi penemuan konsep. Applying (menerapkan) pada tahap ini menerapkan konsep yang dipelajari untuk memecahkan suatu permasalahan. Cooperating (bekerjasama) pada tahap ini diminta untuk belajar secara berkelompok serta berdiskusi dengan peserta didik yang lain. Transfering (mentransfer) pada tahap ini diminta untuk menggunakan pengetahuan dalam konteks dan situasi yang baru. Petunjuk tersebut berguna untuk memberi informasi penggunaan setiap tahapan dari startegi REACT. Kalimat petunjuk ini untuk mengarahkan peserta didik saat belajar dan menjawab soal di setiap tahapan $R E A C T$. Hasil pengembangan petunjuk penggunaan LKPD dapat dilihat pada gambar 4.

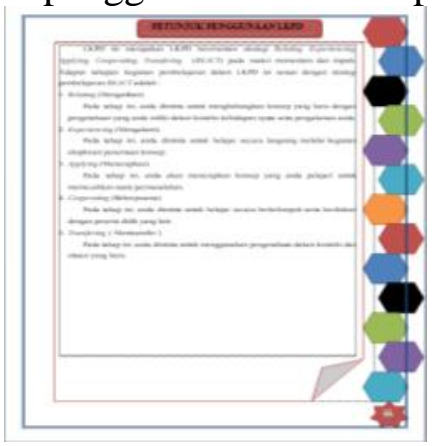

Gambar 4. Hasil Pembahasan Petunjuk Penggunaan LKPD

Pengembangan LKPD halaman pada daftar isi berwarna putih dan terdapat gambar segi enam warna-warni disebelah kanan LKPD dengan garis pinggir berwarna biru. Daftar isi meliputi judul "Daftar Isi" yang bertuliskan jenis huruf time news roman dan font size 14 berwarna hitam. Pada bagian isi ditulis dengan menggunakan jenis huruf time news roman dan font size 12. Isi daftar isi terdapat informasi tentang bagian-bagian dalam LKPD serta nomor halamannya yang memudahkan bagi yang membaca dan menggunakan LKPD. Hasil pengembangan daftar isi dapat pada gambar 5 .

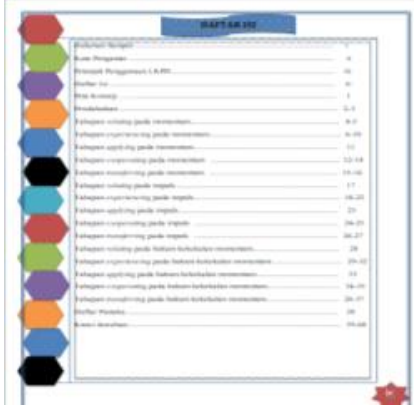

Gambar 5. Hasil Pengembangan Daftar Isi 
Pengembangan LKPD halaman peta konsep berwarna putih dan terdapat gambar segi enam warna-warni disebelah kanan LKPD dengan garis pinggir berwarna biru. Pada halaman daftar isi meliputi judul "Peta Konsep" yang bertuliskan jenis huruf time news roman dan font size 14 berwarna hitam. Pada bagian isi dari peta konsep ditulis dengan berbentuk bagan dan menggunakan jenis huruf time news roman dan font size 12. Bagan peta konsep terdiri dari bagian-bagian konsep materi pokok momentum dan impuls yang ada di dalam LKPD. Peta konsep tersebut menggambarkan isi dari LKPD berorientasi strategi REACT. Peta konsep bertujuan membantu peserta didik untuk mempelajari sains secara bermakna. Hasil pengembangan peta konsep dapat pada gambar 6.

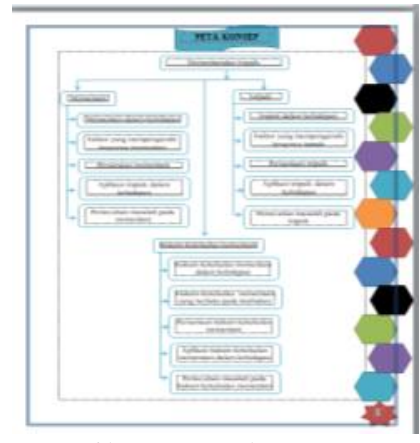

Gambar 6 Hasil Pengembangan Peta Konsep

Pengembangan LKPD halaman pendahuluan berwarna putih dan terdapat gambar segi enam warna-warni disebelah kiri dan kanan LKPD dengan garis pinggir berwarna biru. Pada halaman pendahuluan meliputi judul "Pendahuluan" yang bertuliskan jenis huruf time news roman dan font size 14 berwarna hitam. Pada bagian isi dari pendahuluan ditulis dengan menggunakan jenis huruf time news roman dan font size 12. Isi pendahuluan terdapat Kompetensi Inti (KI), Kompetensi Dasar (KD), indikator pencapaian kompetensi dan tujuan pembelajaran. Pada pendahuluan berdasarkan hasil dari analisis kurikulum yang telah dilakukan. Kompetensi pada kegiatan pembelajaran disesuaikan dengan silabus, indikator pencapaian kompetensi disesuaikan dengan KD. Hasil pengembangan pendahuluan dapat pada gambar 7.

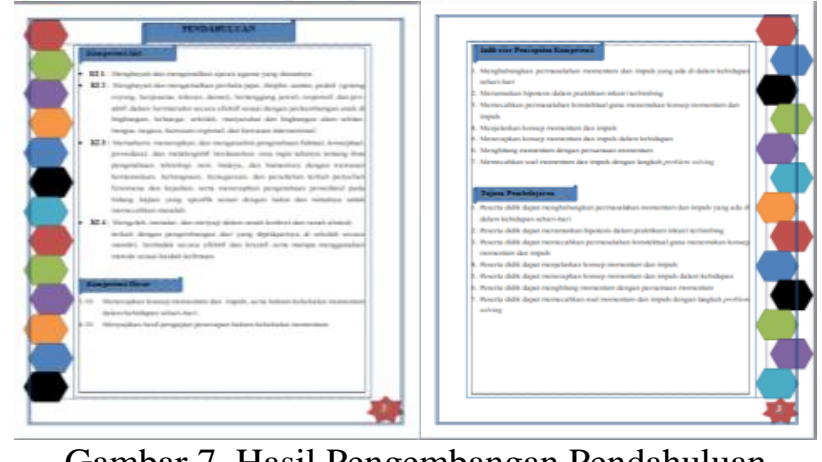

Gambar 7. Hasil Pengembangan Pendahuluan

Pengembangan LKPD halaman relating berwarna putih dan terdapat gambar segi enam warnawarni disebelah kiri dan kanan LKPD dengan garis pinggir berwarna biru. Pada halaman relating meliputi judul ditengah "Relating" yang menunjukkan tahap relating dan judul dipinggir di sebelah kiri "Momentum" yang menunjukkan pada pembahasan materi momentum bertuliskan jenis huruf time news roman dan font size 14 berwarna hitam. Pada bagian isi dari relating ditulis dengan menggunakan jenis huruf time news roman dan font size 12. Isi tahapan dari relating pada sub bahasan momentum terdapat pertanyaan yang berkaitan dengan permasalahan kehidupan seharihari. Peserta didik diajak berpikir dengan mengaitkan konsep dalam kehidupan dengan melihat gambar dan diberi pertanyaan. Pertanyaan dan illustrasi gambar mobil sedan dan mobil truk yang menabrak tembok. Setelah diberikan permasalahan peserta didik diarahkan untuk menjawab pertanyaan dikolom jawaban yang telah disediakan. Hasil pengembangan relating dapat pada gambar 8. 


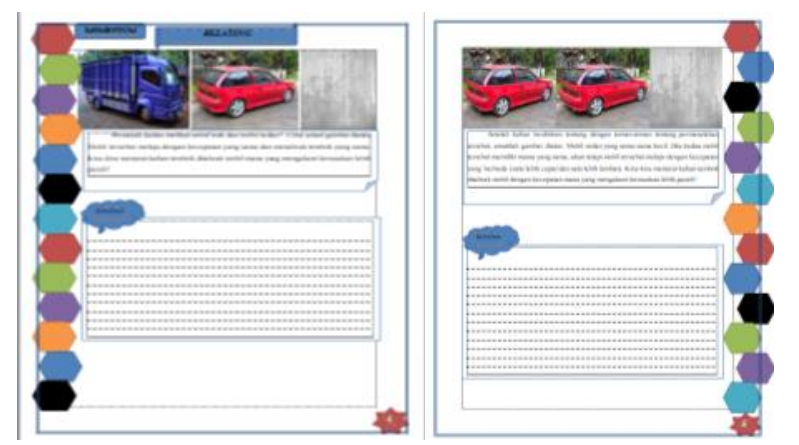

Gambar 8 Hasil Pengembangan Relating Momentum

Pengembangan LKPD halaman experiencing berwarna putih dan terdapat gambar segi enam warna-warni disebelah kiri dan kanan LKPD dengan garis pinggir berwarna biru. Pada halaman experiencing meliputi judul ditengah "Experiencing" yang menunjukkan tahap experiencing bertuliskan jenis huruf time news roman dan font size 14 berwarna hitam. Pada bagian isi dari relating ditulis dengan menggunakan jenis huruf time news roman dan font size 12 . Isi dari experiencing terdapat praktikum inkuiri terbimbing membuktikan kebenaran dugaan dari jawaban pada tahap relating. Isi tahap experiencing terdapat tujuan, rumusan masalah, hipotesis, alat dan bahan, petunjuk percobaan, tabel hasil pengamatan, kolom pertanyaan, kolom kolom jawaban dan kolom pengisian rumus. Lalu peserta didik menjawab dikolom yang telah disediakan. Praktikum pada tahap ini pada sub pokok momentum bertujuan mengetahui faktor-faktor yang mempengaruhi besarnya momentum. Pada tahap ini peserta didik mengalamii dengan melakukan eksplorasi penemuan konsep. Hasil pengembangan experiencing dapat pada gambar 9.
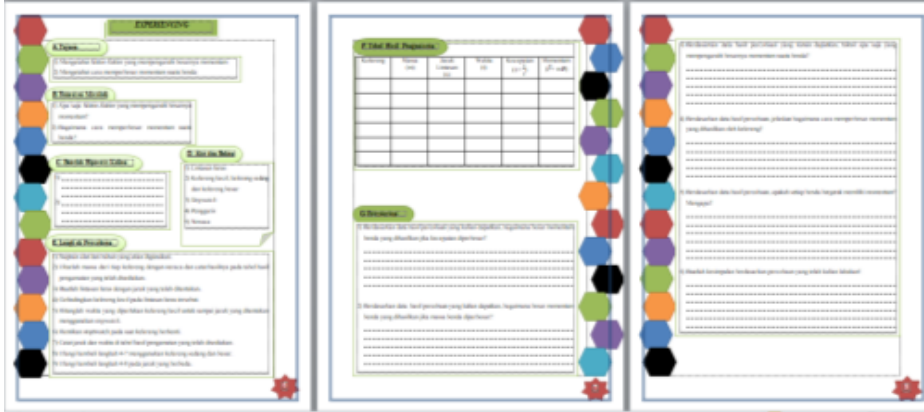

Gambar 9. Hasil Pengembangan Experiencing Momentum

Pengembangan LKPD halaman applying berwarna putih dan terdapat gambar segi enam warnawarni disebelah kiri dan kanan LKPD dengan garis pinggir berwarna biru. Pada halaman applying meliputi judul ditengah "Applying" yang menunjukkan tahap applying bertuliskan jenis huruf time news roman dan font size 14 berwarna hitam. Pada bagian isi dari applying ditulis dengan menggunakan jenis huruf time news roman dan font size 12. Isi tahapan dari applying pada sub bahasan momentum terdapat pertanyaan berupa pilah ganda sebanyak 5 soal. Pertanyaan pada tahap ini berkaitan dengan aplikasi konsep yang telah dipelajari dalam kehidupan sehari-hari. Peserta didik diajak berpikir dengan menjawab soal pilihan ganda. Hasil pengembangan applying dapat pada gambar 10.

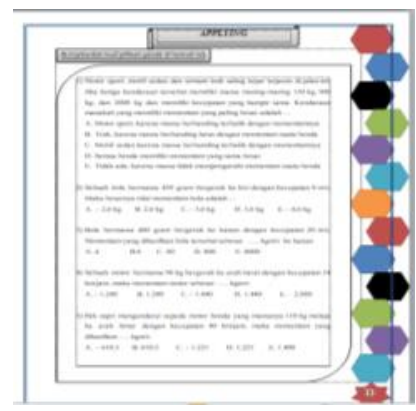

Gambar 10. Hasil Pengembangan Applying Momentum

Pengembangan LKPD halaman cooperating berwarna putih dan terdapat gambar segi enam warna-warni disebelah kiri dan kanan LKPD dengan garis pinggir berwarna biru. Pada halaman 
cooperating meliputi judul ditengah "Cooperating" yang menunjukkan tahap cooperating bertuliskan jenis huruf time news roman dan font size 14 berwarna hitam. Pada bagian isi dari cooperating ditulis dengan menggunakan jenis huruf time news roman dan font size 12. Isi tahapan dari cooperating terdapat soal berupa esai yang terdiri dari 4 soal. Soal tersebut berbeda soal di tahapan applying. Pada tahap ini peserta didik diminta melakukan disukusi kelompok untuk menjawab pertayaan yang ada. Hasil pengembangan cooperating dapat pada gambar 11 .

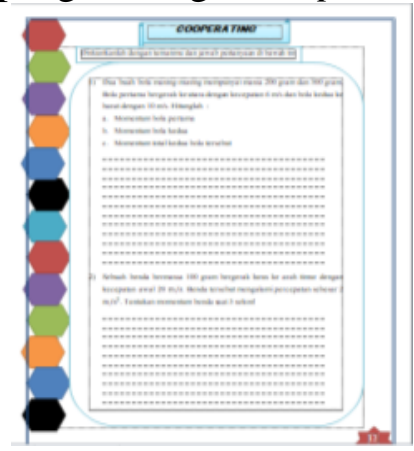

Gambar 11. Hasil Pengembangan Cooperating Momentum

Pengembangan LKPD halaman transferring berwarna putih dan terdapat gambar segi enam warna-warni disebelah kiri dan kanan LKPD dengan garis pinggir berwarna biru. Pada halaman transferring meliputi judul ditengah "Transferring" yang menunjukkan tahap transferring bertuliskan jenis huruf time news roman dan font size 14 berwarna hitam. Pada bagian isi dari transferring ditulis dengan menggunakan jenis huruf time news roman dan font size 12. Isi tahapan dari transferring berupa soal pemecahan masalah (problem solving). Pertanyaan berbentuk soal cerita esai mobil dan pertanyaan dengan langkah-langkah pemecahan masalah (problem solving). Peserta didik diajak berpikir untuk memecahkan masalah soal yang ada di tahap transferring dengan langkah-langkah problem solving yaitu : a) gambarkanlah ilustrasi sesuai dengan permasalahan!; b) apa yang diketahui dan ditanya dari permasalahan tersebut?; c)konsep fisika apa yang sesuai dengan persoalan tersebut?; d) apa alasannya? e) bagaimana persamaan matematika yang dapat digunakan untuk menyelesaikan masalah. Pertanyaan tahap ini pada sub pokok momentum berupa illustrasi Hasil pengembangan transferring dapat pada gambar 12 .

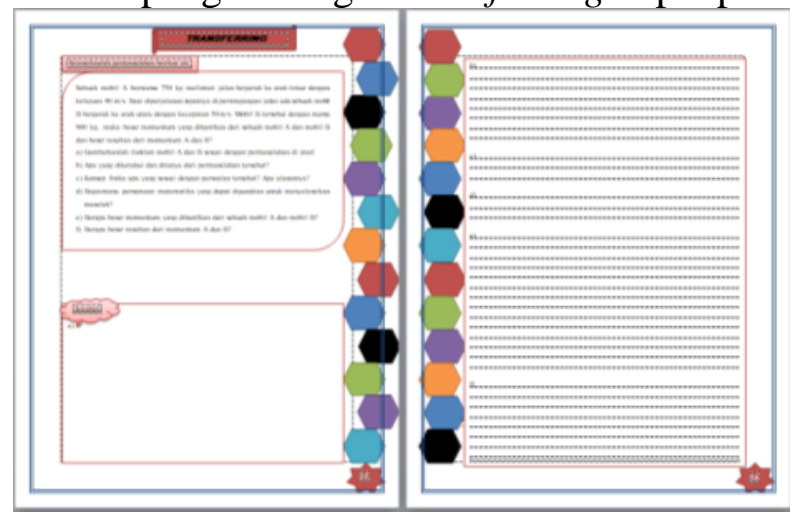

Gambar 12. Hasil Pengembangan Transferring Momentum

Pengembangan LKPD halaman pada daftar pustaka berwarna putih dan terdapat gambar segi enam warna-warni disebelah kiri LKPD dengan garis pinggir berwarna biru. Pada halaman daftar isi meliputi judul "Daftar Pustaka" yang bertuliskan jenis huruf time news roman dan font size 14 berwarna hitam. Pada bagian isi dari daftar isi ditulis dengan menggunakan jenis huruf time news roman dan font size 12. Isi daftar pustaka berupa sumber dari LKPD yang dibuat dimasukkan ke dalam daftar pustaka untuk menghindari plagiasi terhadap karya orang lain. Daftar pustaka beriskan daftar buku refrensi dalam pembuatan LKPD. Daftar pustaka digunakan ditulis sesuai format penulisan daftar pustaka. Hasil pengembangan daftar pustaka dapat pada gambar 13. 


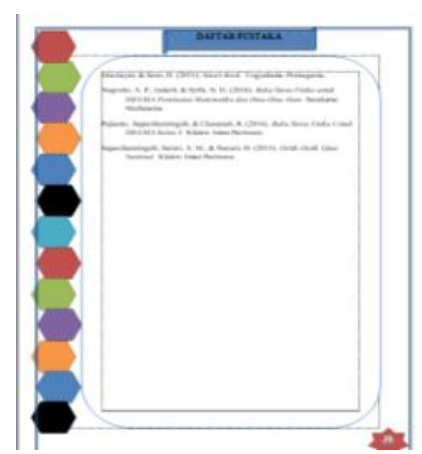

Gambar 13 Hasil Pengembangan Daftar Pustaka

Pengembangan LKPD halaman pada kunci jawaban berwarna putih dengan garis pinggir berwarna biru. Pada halaman daftar isi meliputi judul "Kunci Jawaban" yang bertuliskan jenis huruf time news roman dan font size 14 berwarna hitam. Pada bagian isi dari kunci jawaban ditulis dengan menggunakan jenis huruf time news roman dan font size 12. Isi kunci jawaban berupa Kunci jawaban ini berisikan kunci jawaban dari setiap tahapan strategi REACT pada LKPD.Hasil pengembangan kunci jawaban dapat pada gambar 14.

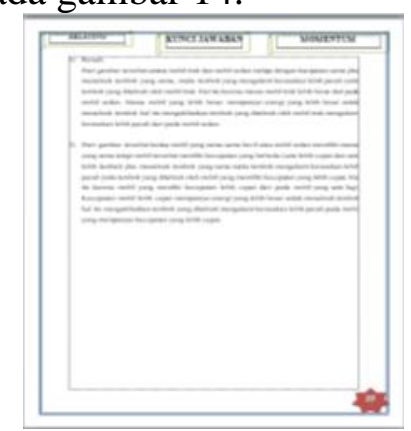

\subsubsection{Develop (Pengembangan)}

\section{Gambar 14 Hasil Pengembangan Kunci Jawaban}

Berdasarkan persentase rata-rata dari uji validitas aspek media, materi, dan bahasa yang dilakukan oleh 2 orang pakar ahli dapat diambil kesimpulan bahwa LKPD berorientasi REACT strategy pada materi momentum dan impuls yang telah dikembangkan tergolong dalam kategori valid dengan persentase rata-rata yaitu $79,3 \%$ dari $100 \%$. Hal ini berarti LKPD berorientasi REACT strategy pada materi momentum dan impuls sudah memenuhi aspek media, materi, dan bahasa. Hasil validitas yang telah diberikan oleh validator sudah valid, boleh digunakan dengan melakukan revisi kecil pada produk. Hasil uji validitas LKPD dapat dilihat pada tabel 3.

Tabel 3 Hasil Uji Validitas LKPD

\begin{tabular}{ccc}
\hline No & Persentase & Kategori \\
\hline Media & $73,3 \%$ & Valid \\
Materi & $84,5 \%$ & Sangat valid \\
Bahasa & $80 \%$ & Valid \\
$\boldsymbol{V}_{\boldsymbol{a h}}$ & $79,3 \%$ & Valid \\
\hline
\end{tabular}

\subsection{Pembahasan}

Pengembangan LKPD berorientasi REACT strategy menggunakan langkah-langkah penelitian $R \& D$ dengan model 3-D kegiatan yang dilakukan pada pengembangan ini yaitu define (pendefinisian), design (perancangan), develop (pengembangan). Tujuan dari pengembangan ini yaitu untuk menghasilkan dan mendeskripsikan karakteristik LKPD berorientasi REACT strategy, sehingga dapat digunakan sebagai sumber referensi untuk mengembangkan LKPD berorientasi REACT strategy pada materi yang lain. Langkah pertama yang dilakukan yaitu pada tahap define dengan cara menyusun instrumen penelitian, observasi, analisis kurikulum, analisis perangkat pembelajaran, analisis kebutuhan guru dan analisis kebutuhan peserta didik.

Penyusunan instrumen penelitian pada lembar observasi aspek yang diamati ada 4 yaitu kurikulum yang digunakan, bahan ajar yang digunakan guru dalam kegiatan pembelajaran fisika, teknik guru dalam membimbing peserta didik dalam pembelajaran fisika, dan penyampaian materi 
oleh guru mata pelajaran fisika. Pada lembar review dokumen kurikulum ada dua aspek yang diamati yaitu komponen kurikulum dan karekteristik kurikulum. Aspek komponen kurikulum terdiri dari 2 indikator yaitu cover atau halaman judul dan lembar pengesahan dengan menghasilkan 9 item pernyataan. Pada aspek karekteristik kurikulum terdiri dari 6 indikator yaitu pendahuluan, kegiatan pembelajaran, indikator, penilaian, alokasi waktu dan sumber belajar dengan menghasilkan 17 item pernyataan.

Pada lembar review dokumen LKPD ada dua aspek yang diamati yaitu komponen LKPD dan karekteristik LKPD. Aspek komponen LKPD terdiri dari 4 indikator yaitu tujuan pembelajaran, petunjuk penggunaan LKPD, pendahuluan dan tugas dengan menghasilkan 10 item pernyataan. Pada aspek karekteristik LKPD terdiri dari 5 indikator yaitu relating, experiencing, applying, cooperating, dan transfering dengan menghasilkan 10 item pernyataan.

Pada observasi awal dan analisis kurikulum yang dilakukan mendapatkan indetifikasi masalah bahwa di SMAN 9 Kota Bengkulu belum menggunakan LKPD yang menerapkan 5M di dalam pembelajarannya atau pembelajaran yang berpusat pada peserta didik dan LKPD menerapkan pelajaran fisika ke dalam kehidupan sehari-hari. Hasil analisis kurikulum ini diambil berdasarkan Rencana Pelaksanaan Pembelajaran (RPP). Pada kompetensi inti dan kompentensi dasar, indikator pencapaian kompetensi, tujuan pembelajaran, materi pembelajaran, metode pembelajaran dan kegiatan pembelajaran tersebut digunakan sebagai masukan awal dan acuan dalam pembuatan LKPD. Pemilihan REACT strategy merupakan hasil analisis kurikulum yang sesuai dengan kurikulum 2013.

Hasil analisis perangkat pembelajaran LKPD di SMA Negeri 9 Kota Bengkulu didapatkan hasil bahwa LKPD yang digunakan di sekolah tersebut belum berorientasi REACT strategy. LKPD tersebut belum dilengkapi dengan tahapan dari REACT strategy yang mana belum dilengkapi dengan praktikum inkuiri terbimbing dan serta belum dilengkapi dengan langkah-langkah problem solving (pemecahan masalah) dalam langkah-langkah menyelesaikan soal.

Langkah selanjutnya yaitu design (perancangan) dilakukan dengan kegiatan merancang atau mendesain produk dan instrumen. Rancangan produk dan instrumen ini berdasarkan hasil analisis kebutuhan dan studi literatur pada tahap define yaitu observasi, analisis kurikulum, analisis perangkat pembelajaran, dan data sekunder analisis kebutuhan pengembangan. Rancangan LKPD digunakan untuk menyusun draft LKPD yaitu penetapan kompetensi dasar, kompentensi inti, indikator pencapaian dan tujuan. Layout LKPD yang dikembangkan terdiri atas cover, kata pengantar, daftar isi, peta konsep, petunjuk pengunaan LKPD, soal dan praktikum yang sesuai dengan tahapan REACT, kunci jawaban, dan daftar pustaka. Soal dan praktikum tahapan REACT strategy ini terdiri dari 3 pokok pembahasan materi momentum dan impuls. Pada tahap relating peserta didik terdapat permasalahan konstektul, pada tahap experiencing terdapat praktikum inkuiri terbimbing. Pada tahap applying terdapat soal pilihan ganda, tahap cooperating soal berbentuk esai yang menuntun peserta didik bekerja sama dan tahap transferring terdapat soal pemecahan masalah (problem solving). Langkah terakhir yang dilakukan dalam penelitian ini yaitu develop (pengembangan) dilakukan dengan kegiatan validasi dan revisi. Validasi ini terdiri dari persentase aspek media, materi, dan bahasa.

\subsubsection{Kelayakan LKPD Fisika Oleh Validator Ahli}

Tahap ini dilakukan untuk mendeskripsikan kelayakan LKPD fisika berorientasi REACT strategy. Hasil uji validitas pada aspek media yang terdiri dari 12 butir penilaian yaitu dengan persentase sebesar 73,3\% yang berada pada kategori valid dengan melakukan revisi kecil. Hasil uji validitas pada aspek materi terdiri dari 20 butir penilaian yaitu dengan persentase sebesar $84,5 \%$ yang berada pada kategori sangat valid. Hasil uji validitas yang terakhir pada aspek bahasa terdiri dari 4 butir penilaian yaitu dengan persentase sebesar $80 \%$ yang berada pada kategori valid dengan melakukan revisi kecil. Berdasarkan hasil secara keseluruhan dari uji validasi aspek media, aspek materi, dan aspek bahasa yang telah dilakukan oleh 2 orang pakar ahli dapat dikatakan bahwa LKPD berorientasi REACT strategy pada materi momentum dan impuls yang telah dikembangkan dapat dikategorikan valid dengan persentase rata-rata $\mathbf{7 9 , 3 \%}$. Hal ini dapat disimpulkan bahwa LKPD fisika berorientasi REACT strategy sudah layak digunakan dengan melakukan revisi kecil. 


\subsubsection{Karakteristik LKPD Fisika yang Dikembangkan}

Produk akhir dari penelitian dan pengembangan ini yaitu LKPD berorientasi REACT strategy dengan karakteristik umum yang bersikan petunjuk pengunaan LKPD serta tahapan-tahapan REACT strategy. LKPD ini berbeda dengan LKPD yang digunakan di sekolah karena di dalam LKPD terdapat soal dan kegiatan praktikum yang membuat peserta didik menerapkan konsep materi yang didapat saat belajar ke dalam kehidupan nyata.

Karakteristik khusus LKPD yang dikembangkan yaitu LKPD berorientasi REACT strategy dimana LKPD ini memuat tahapan relating, experiencing, applying, cooperating dan transfering dengan sub pokok materi momentum, impuls, dan hukum kekekalan momentum. Pada lembar LKPD tahap relating ini terdapat penyajian permasalahan kontekstual dengan soal yang berisikan illustrasi gambar tentang masalah fisika yang ada di kehidupan sehari-hari. Permasalahan yang diberikan dapat melatihkan peserta didik untuk dapat menghubungkan materi dengan aplikasi kehidupan nyata. Pada tahap experiencing ini mengajak peserta didik untuk melakukan praktikum inkuiri terbimbing yang bertujuan untuk memecahkan permasalahan konstekstual guna menemukan konsep fisika. Prosedur percobaan yang mengarahkan pada aktivitas untuk eksplorasi penemuan konsep di tahap experiencing. Tahap applying ini dilengkapi dengan soal dapat melatihkan peserta didik untuk dapat menerapkan konsep materi yang telah dipelajari terhadap pertanyaan yang diberikan yang telah dipelajari dalam kehidupan sehari-hari. Pada tahap cooperating terdapat soal esai yang dapat membuat peserta didik untuk berkomunikasi dan bekerja sama. Soal pada tahap cooperating berbeda dengan soal pada tahap applying. Pada tahap transfering terdapat soal problem solving untuk memecahkan masalah yang diberikan, soal tersebut dijawab dengan dilakukan kegiatan melalui tahapan dari problem solving. Permasalahan yang diberikan ini dapat melatihkan peserta didik untuk dapat memecahkan masalah.

Penelitian ini sesuai dengan penelitian yang berjudul "Pengembangan Modul Berbasis Relating, Applying, Cooperating, and Transferring (REACT) pada Materi Jamur untuk Meningkatkan Kemampuan Berpikir Kritis Siswa Kelas X SMA" menyatakan bahwa karakteristik modul yang dikembangkan mengacu pada sintak pembelajaran REACT yang dapat digunakan dalam kegiatan pembelajaran peserta didik dibimbing untuk menemukan konsep melalui aktivitas $R E A C T$, guru sebagai fasilitator (18).

\section{SIMPULAN DAN SARAN}

\subsection{Simpulan}

Berdasarkan data yang diperoleh tersebut hal ini berarti LKPD fisika berorientasi REACT strategy yang telah dikembangkan sudah memenuhi aspek media, materi, dan aspek bahasa. Hal ini dapat disimpulkan bahwa LKPD fisika berorientasi REACT strategy sudah layak digunakan dengan melakukan revisi kecil. Karakteristik LKPD yang dikembangkan yaitu LKPD berorientasi REACT strategy dimana LKPD ini memuat tahapan relating, experiencing, applying dan transfering.

\subsection{Saran}

Adapun saran untuk penelitian selanjutnya adalah sebagai berikut: 1) LKPD yang dibuat masih memiliki keterbatasan penelitian yaitu belum dilakukan uji keterbacaan dan uji coba terbatas kepada peserta didik dikarenakan adanya pandemi covid-19 yang berakibat sekolah diliburkan. 2) Pada tahap experiencing sebaiknya menggunakan inkuiri bebas dan pada tahap transferring sebaiknya menggunakan praktikum problem solving. 3) Penelitian dan pengembangan LKPD berorientasi REACT strategy pada materi yang berbeda.

\section{UCAPAN TERIMA KASIH}

Penulis mengucapkan terima kasih kepada validator ahli (Dr. Iwan Setiawan, M.Sc. dan Andik Purwanto, M.Si.) dan pihak lain yang telah membantu penulis menyelesaikan penelitian ini.

\section{DAFTAR PUSTAKA}

1. Noviana S, Connie, Hamdani D. Penerapan Model Inkuiri Terbimbing Untuk Keterampilan 
Berpikir Kritis Siswa Kelas X IPA.3 SMA Negeri 3 Bengkulu Tengah. J Pembelajaran Fis. 2017;1(1):28-37.

2. Oktalia Y, Sakti I, Hamdani D. Pengaruh Minat Dan Motivasi Pada Penerapan Model Diskoveri Berbantuan Media Animasi Terhadap Hasil Belajar Fisika Di SMA Negeri 4 Kota Bengkulu. J Ilmu dan Pembelajaran Fis. 2017;1(1):87-95.

3. Putri DH, Risdianto E, Sutarno. Identifikasi Keterlaksanaan Praktikum Fisika SMA dan Pembelajaran Abad 21. J Petrol. 2013;369(1):1689-99.

4. Pendidikan TPI. Ilmu dan Aplikasi Pendidikan. Jakarta: Imperial Bhakti Dharma; 2009.

5. Majid A. Perencanaan Pembelajaran. 2016: Remaja Rosdakarya; 2016.

6. Widodo S. Pengembangan Lembar Kegiatan Peserta Didik (LKPD) Berbasis Pendekatan Saintifik untuk Meningkatkan Keterampilan Penyelesaian Masalah Lingkungan Sekitar Peserta Didik di Sekolah Dasar. JPIS J Pendidik Ilmu Sos. 2017;26(2):189-204.

7. Putri RA, Marzal J, Pendidikan P, Universitas M. Pengembangan LKPD Berbasis Problem Solving Berbantuan Robocompass pada Materi Sistem Koordinat Kartesius. 2018;III(1):3140.

8. Murlin A, Tawil M, Samad A. Penerapan Metode Pembelajaran Eksperimen dengan LKPD Terstruktur Terhadap Peningkatan Hasil Belajar Fisika Peserta Didik Kelas X SMA Negeri 2 Sukamaju. 2017;3(2):176-86.

9. Ningrum E. Pengembangan Strategi Pembelajaran. Bandung: Purba Setia; 2013.

10. Kristiana Dewi N, Siti Aminah N, Sukarmin S. Pengembangan Modul Fisika Berbasis Relating, Experiencing, Applying, Cooperating, and Transferring (React) Pada Materi Alat Optik Untuk Meningkatkan Kecerdasan Majemuk Dan Kreativitas Siswa. Inkuiri. 2016;4(2):47-56.

11. Yudiprasetya IDP, Suarni N kt, Rati NW. Pengaruh Strategi REACT dan Motivasi Belajar Terhadap Hasil Belajar Matematika Siswa Kelas V. 2014;2(1):1-10.

12. Bílgín AK, Yürükel FND, Yígít N. The Effect of a Developed REACT Strategy on the Conceptual Understanding of Students: "Particulate Nature of Matter." J Turkish Sci Educ. 2017;14(2):65-81.

13. Halimatusadiah AMA, Maulana M, Syahid AA. Pengaruh Pendekatan Kontekstual Berstrategi REACT Terhadap Kemampuan Pemahaman Matematis dan Motivasi Belajar Siswa Sekolah Dasar. Mimb Sekol Dasar. 2017;4(3):203.

14. Adawiyah R Al, Lesmono AD, Prastowo SHB. Pengembangan Bahan Ajar Fisika Berupa Buku Berbasis REACT (Relating, Experiencing, Applying, Cooperating, and Transferring) Pada Pembelajaran Fisika Di SMA. J Pembelajaran Fis. 2018;7(2):202-9.

15. Anggitcahyowibowo H, Endang P, Yudyanto. Pengembangan Bahan Ajar fisika Berbasis REACT (Relating, Experiencing, Applying, Cooperating, Transferring). J Pembelajaran Fis. 2008;7(2):202-9.

16. Sugiyono. Metode Penelitian dan Pengembangan (Research and Development). Bandung: Alfabeta; 2017.

17. Akbar S. Instrumen Perangkat Pembelajaran. Bandung: Remaja Rosdakarya; 2017.

18. Nugroho ES, Prayitno BA, Maridi. Pengembangan Modul Berbasis Relating, Applying, Cooperating, and Transferring (REACT) pada Materi Jamur untuk Meningkatkan Kemampuan Berpikir Kritis Siswa Kelas X SMA. J FKIP UNS. 2018;7(1):63. 